\title{
DELTA AND UPPER EGYPT BUFFALO FARMING SYSTEMS: ASURVEY COMPARISON
}

\author{
N.H. Fahim ${ }^{1}$, S.A.M. Abdel-Salam ${ }^{1}$,W. Mekkawy ${ }^{2}$, Ahmed Ismael ${ }^{1}$, S. Abou-Bakr ${ }^{1}$, Manal El \\ Sayed $^{2}$, M.A.M. Ibrahim ${ }^{1}$
}

1-Department of Animal Production, Faculty of Agriculture, Cairo University, Giza, Egypt, 2-Department of Animal Production, Faculty of Agriculture, Ain Shams University, Cairo, Egypt

\section{Received: 13/11/2017}

\section{SUMMARY}

Buffaloes play a vital role in the Egyptian food security, providing the local market by $44 \%$ and $39 \%$ of milk and red meat, respectively. The main objective of this study was to compare between the buffalo farming systems in Upper Egypt (UEg) and Delta Egypt (DEg). A survey was conducted to study the characteristics of dairy buffalo production in two ecologically distinctive zones: the UEg and the DEg. Data were collected throughout interviews with farmers of 1811 buffalo herds keeping 12450 heads of Egyptian buffaloes. The study was done from July 2010 to January 2011 using comprehensive and structured questionnaire. Results indicated that the averages of farm size per household and herd size of buffaloes were 1.1 ha and 3 heads in UEg compared to 1.5 ha and 10 heads in DEg, respectively. Means of daily milk yield, total milk yield, lactation period and longevity were $7.7 \mathrm{~kg}, 1826 \mathrm{~kg}, 7.7$ months and 5.5 parities in UEg buffaloes, respectively. Whereas, these estimates were $8.2 \mathrm{~kg}, 1899 \mathrm{~kg}, 7.5$ months, 4.7 parities in DEg buffaloes, respectively. Similar traditional and low management level was practiced in the two studied zones. Five and six principal components were extracted in UEg and DEg explaining $67.9 \%$ and $82.1 \%$ of the total variation in the original variables, respectively. Development of the Egyptian buffaloes needs suitable breeding program, using untraditional feed resources, good veterinary and extension services, development of village markets and introduction of storage and grading products facilities. The buffalo farming systems in Egypt needs more studies to recognize the opportunities of improvement and to maximize the productivity and profitability of the system.

\section{INTRODUCTION}

The Egyptian buffaloes (Bubalus bubalis) belong to the river type. They were brought to Egypt during the middle of the $7^{\text {th }}$ century from India, Iran and Iraq (Moioli and Borghese, 2005). They are marked by well adaptive capacity to humid hot climate (Das et al. 2017), resistance to many diseases and parasites (El Nahas et al., 2013) and proficiency of use low quality roughage (Wanapat and Chanthakhoun, 2015). Besides, buffaloes produce milk with high fat content which is more preferred by Egyptians than the bovine one. Moreover, Egypt is the main African country, keeping a large number of buffaloes by about 3.9 million heads (FAOSTAT, 2014). About $42 \%$ of the buffalo population structure is dairy cows, $6 \%$ bulls, $32 \%$ heifers, and $20 \%$ male calves (Ibrahim and Abdelrazek, 2012).

Buffaloes play a vital role in the Egyptian food security, providing the local market with $44 \%$ and $39 \%$ of milk, and red meat, respectively (FAOSTAT, 2014).About $97 \%$ of the Egyptian buffalo population is raised in small size herds Ministry of Agricultural and Land Reclaimed (MALR, 2011) under traditional mixed crop/livestock farming system, which is the main livestock farming system in Egypt (Khalil and Sammour, 2006). Within this typology, buffaloes do not receive the same attention as cattle in the intensive production system. Therefore, numbers of buffaloes and their contribution in milk and red meat in the Egyptian local market decline year by year in comparison to the specialized dairy cattle. Studying the buffalo farming systems is an urgent need to recognize the features, components, strengths, weaknesses, opportunities and constraints within these farms to design policies and determine the strategies for improving these farming systems. About $57 \%$ of buffaloes are kept in Delta, in the Northern of Egypt and $43 \%$ are kept in the mid and UEg in the Southern Egypt (Galal and Elbeltagy, 2006).

UEg and DEg are two different distinctive zones that are different in climate, rainfall and farmland's fertility. Few studies observed the characteristics of buffalo production in Delta and Upper Egypt. Therefore, the main objective of this study was to compare between the buffalo production performance in UEg and DEg. Also, clarify the different characteristics between buffalo farming systems in UEg and DEg.

\section{MATERIAL AND METHODS}

\section{Study Areas:}

The study areas included two ecologically different zones: Upper Egypt (UEg) and Delta Egypt (DEg). Depending on the direction flow of the River Nile which starts from highlands of East Africa Northwards to the Mediterranean Sea, DEg is the Northern part of Egypt. While, UEg is the Southern part of Egypt. The Nile Delta is formed in the 
Northern Egypt, where the Nile River spreads out and drains into the Mediterranean Sea. This region extends from Alexandria in the West to Port Said in the East. Moreover, UEg extends from the Giza in the north to Aswan in the south.

The climate of UEg is more severe than that of DEg. It is characterized by mild, dry winters and very hot summers. Moreover, the rainfall is scarce when compared to winter plentiful rainfall in DEg. Besides, UEg agricultural lands are less fertile, and farming system is less intensive than those of DEg. In the current study, UEg was represented by the governorates of AL-Fayoum, AL-Minya, Assiut, Beni-Suef and Sohag. While, the DEg was represented by the governorates of AL-Behira, ALMenoufia, AL-Qalubiya, AL-Sharkia and Kafr ALSeihkh. The population of Egyptian buffalo indicated that $69 \%$ of all buffaloes in Egypt are kept in these selected ten governorates (MALR, 2011).

\section{Sampling Method:}

Stratified sampling method was done. The sampling frame was divided into two groups. The first group was for Upper Egypt (UEg) and the second was for Delta Egypt (DEg), each group contained five non-overlapping groups or strata according to the size of the buffalo population in each governorate. Thereafter, random sampling was used to select a sample of subjects (buffalo holders) from each stratum.

\section{Data Collection:}

Data were collected from 1811 buffalo herds. These herds were scattered in 55 centers (administrative area containing a number of villages) located within the ten selected governorates of Delta and Upper Egypt. The total number of buffaloes was 12450 heads. Heads of other animals including cattle, sheep, goat, horses and donkeys were 23074 kept within these farms. Number of governorates, centers, buffalo herds, buffalo's heads and other animals in Delta and Upper Egypt are shown in Table (1).

Data were collected during six months from July 2010 to January 2011. A structured questionnaire was designed to gather data throughout face-to-face interviews. Sampled buffalo owners were randomly chosen. Comprehensive and detailed information such as buffalo owners' characteristics type of farm animal, crop production, herd structure of buffalo, reproductive performance, production characteristics, feeding, milking system, and farm products were included within the questionnaire.

Table 1. Numbers of governorates, centers, buffalo herds, buffalo and animals* in Delta and Upper Egypt

\begin{tabular}{llcccc}
\hline Zone & Governorate & Centers & Buffalo herds & Buffalo & Animals \\
\hline & AL -Fayoum & 4 & 84 & 224 & 605 \\
& AL -Minya & 4 & 275 & 1102 & 2541 \\
Upper Egypt (UEg) & Assiut & 4 & 155 & 364 & 1019 \\
& Beni-suef & 3 & 132 & 446 & 1522 \\
& Sohag & 4 & 202 & 649 & 1669 \\
\hline Sub-total & & 19 & 848 & 2785 & 7356 \\
& AL-Behira & 5 & 257 & 3771 & 6290 \\
Delta Egypt (DEg) & AL -Menoufia & 8 & 181 & 1288 & 2218 \\
& AL -Quliubiya & 3 & 122 & 2018 & 2583 \\
& AL -Sharkia & 13 & 194 & 1656 & 2878 \\
& Kafr EL-Sheikh & 7 & 209 & 932 & 1749 \\
\hline Sub-total & & 36 & 963 & 9665 & 15718 \\
\hline Total & & 55 & 1811 & 12450 & 23074 \\
\hline
\end{tabular}

*Animals including cattle, sheep, goats, donkeys and horses.

\section{Data Analysis:}

Collected data were analyzed using IBM SPSS Statistics, version 21 (2012). Descriptive statistical procedure was used to estimate means and standard deviation of different studied variables. The chisquare (I) test was used to determine the significant differences among the different frequencies categories. Analysis of Variance (ANOVA) was carried out to check the existence of statistically significant differences among means of studied traits of the two zones; UEg and DEg.

The objective of principal component analysis (PCA) is to account for the maximum portion of the variance present in the original set of variables with a minimum number of composite variables. It assumes that the unique variance represents a small portion of the total variance (Sadek et al., 2006 and Pundir et al., 2011). PCA extracts linear combinations of the original variables whose weights correspond to the 
eigenvectors of the correlation matrix. This approach allows a large part of the total variation to be concentrated in a small number of standardized uncorrelated variables. The PCA was performed using the XLSTAT 2016. PCA analysis was carried out in this study to identify the factors to represent the variables, so as to explain buffalo farming systems, in Egypt.

\section{RESULTS}

\section{Salient Characteristics:}

Human Resources:

In the current study, all sampled buffalo owners and landholders were males. However, both family genders contributed to the farming activities from an early age. Furthermore, it is observed that the majority of buffalo farms were family managed. The data presented in Table (2) show the contribution percentages of family males and females in buffalo farms tasks. It is indicated that females had an obvious role in herds' management. They were involved in various farm activities particularly that do not require great bodily effort such as calves and small calves rearing. Moreover, milking, milk processing and marketing were more likely done by females.

Characteristics of farmers according to educational level, qualification and purpose of setting up the activity are presented in Table 2. Educational level in DEg was better than in UEg. Table 2 showed that purpose of the activity such as milk and calves production were interrelated activities, where more than $70 \%$ of buffalo farmers practiced both two activities in UEg and DEg.

\section{Livestock:}

Livestock of small farms are frequently located close to or within the farmer's house. In the current study, the majority of buffaloes were maintained tied in closed barns. From the data collected, it was noticed that the buffalo herd size average in UEg did not exceeded 3 heads when compared to an average of 10 heads in those of DEg. Also, Figure (1) shows that buffaloes in DEg represented $66 \%$ of all ruminants in the household compared to $44 \%$ in UEg.

Table 2. Characteristics of farmers in Delta and Upper Egypt

\begin{tabular}{|c|c|c|c|c|}
\hline & \multicolumn{2}{|c|}{ Upper Egypt (UEg) } & \multicolumn{2}{|c|}{ Delta Egypt (DEg) } \\
\hline & Frequency & $\%$ & Frequency & $\%$ \\
\hline \multicolumn{5}{|l|}{ Labor Gender: } \\
\hline Male & 1233 & $68^{\mathrm{a}}$ & 1568 & $72^{\mathrm{a}}$ \\
\hline Female & 567 & $32^{\mathrm{a}}$ & 612 & $28^{\mathrm{a}}$ \\
\hline \multicolumn{5}{|l|}{ Educational level: } \\
\hline College degree & 75 & $9^{a}$ & 132 & $14^{\mathrm{a}}$ \\
\hline Intermediate degree & 208 & $24^{\mathrm{a}}$ & 289 & $30^{\mathrm{a}}$ \\
\hline Literate & 228 & $27^{\mathrm{a}}$ & 253 & $26^{\mathrm{a}}$ \\
\hline Illiterate & 337 & $40^{\mathrm{a}}$ & 289 & $30^{\mathrm{a}}$ \\
\hline \multicolumn{5}{|l|}{ Educational qualifications: } \\
\hline Agricultural & 99 & $12^{\mathrm{a}}$ & 193 & $20^{\mathrm{b}}$ \\
\hline Non-agricultural & 187 & $22^{\mathrm{a}}$ & 242 & $25^{\mathrm{a}}$ \\
\hline Without qualification & 562 & $66^{\mathrm{a}}$ & 528 & $55^{\mathrm{a}}$ \\
\hline \multicolumn{5}{|l|}{ Purpose of the activity: } \\
\hline Milk production & 236 & $28^{\mathrm{a}}$ & 241 & $25^{\mathrm{a}}$ \\
\hline Milk and calves production & 612 & $72^{\mathrm{a}}$ & 722 & $75^{\mathrm{a}}$ \\
\hline
\end{tabular}

${ }^{\mathrm{a}, \mathrm{b}}$ Different superscripts indicate significant differences between the zone categories $(P<0.05)$ for $\chi^{2}$ test.
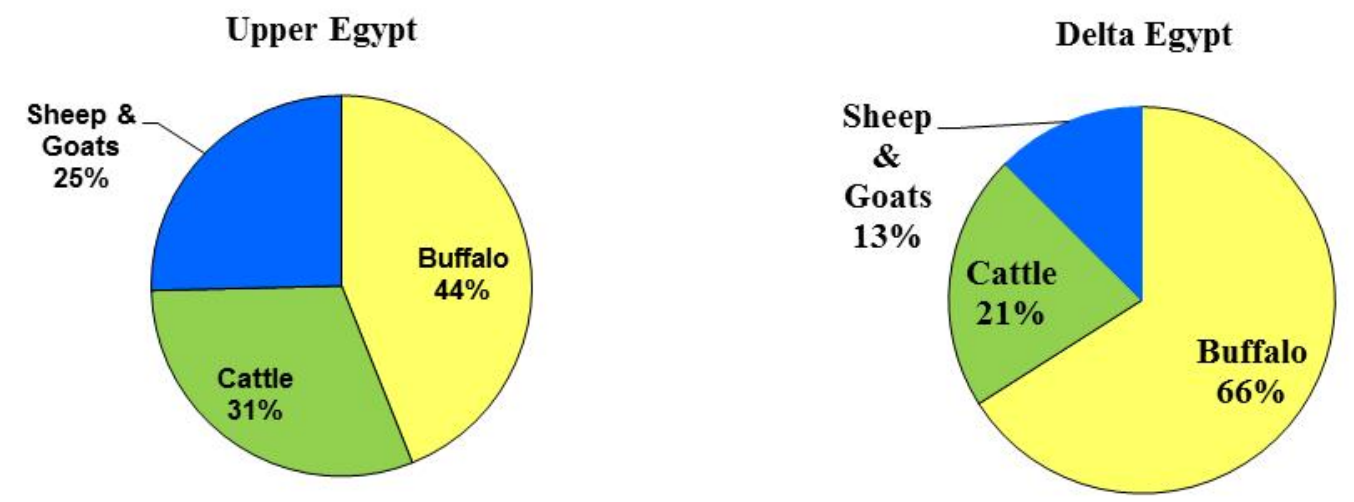

Figure 1. Livestock composition of the surveyed farms in Delta and Upper Egypt 
Figure (2) indicates that lactating buffaloes are dominated in all sampled herds as they are responsible for providing milk and calves. Conversely, bulls, since only a few numbers are required for breeding, so their percentage did not exceed $1 \%$ from the total buffaloes in our study sample. Moreover, the majority of farmers did not own a buffalo bull. Because the buffalo cow number to be bred, per farmer, is very small.

All lactating buffaloes involved in the current study were hand-milked twice daily under low hygienic conditions. About $94 \%$ of the buffalo farmers of UEg used some of their raw milk to produce dairy products. These products are mainly cheese, cream and butter. Only $78 \%$ for the buffalo farmers of DEg did the same. Primitive processing methods were followed in both two zones. Some of the liquid milk and dairy products were consumed by family members and the rest were sold through village markets. The services of transportation, storage and grading dairy products were not available at all.

\section{$\square$ Upper Egypt $\quad \square$ Delta Egypt}

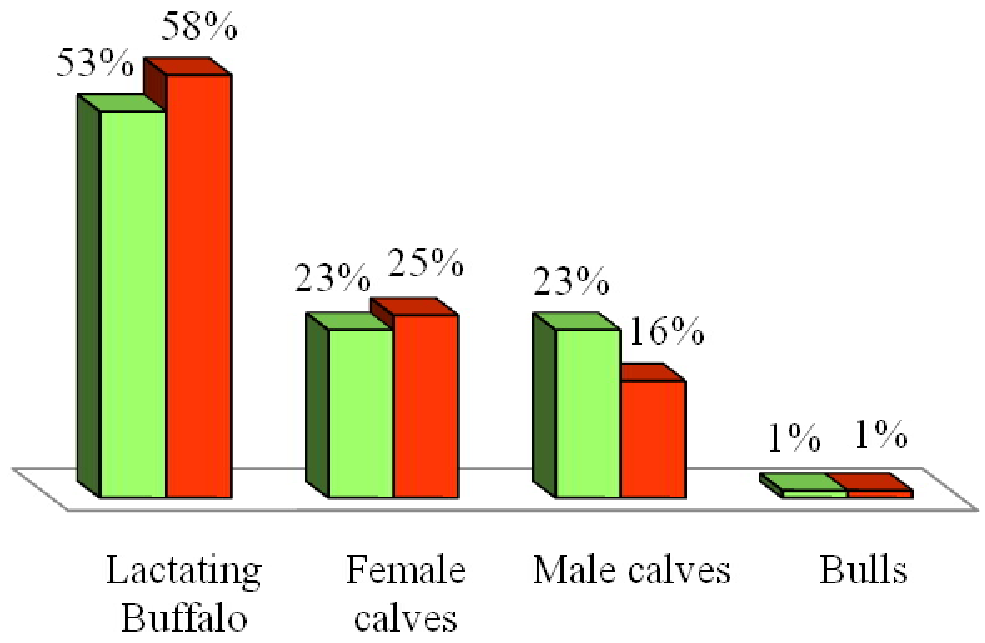

Figure 2. Structure of buffalo herds in Delta and Upper Egypt

Crops:

The total area of agricultural lands owned by farmers in the present study were 2,254 feddans ( 912 ha) in UEg and 3,679 feddans $(1,489 \mathrm{ha})$ in DEg. The majority of buffalo farmers cultivated their owned farms $(63 \%), 14 \%$ of the farmers cultivated rented farms, and $23 \%$ of the farmers combined between both of owned and rented farms. On the other hand, $50 \%$ of UEg buffalo farmers cultivated their owned farms while $33 \%$ of them cultivated rented land ones and $17 \%$ of the framers combined the two patterns (Figure 3).

\section{Upper Egypt}

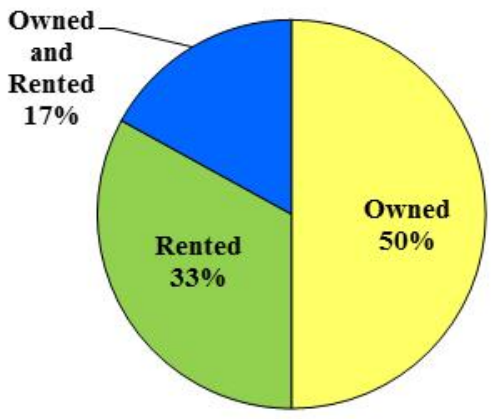

\section{Delta Egypt}

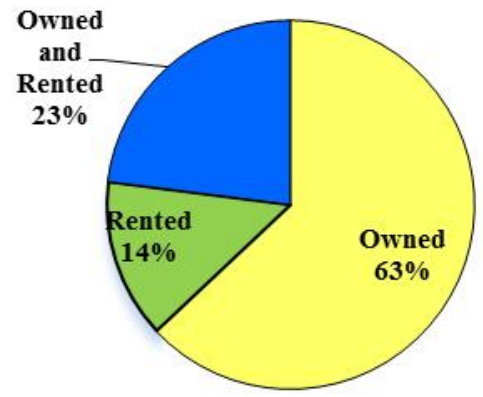

Figure 3. Landholding patterns of farms in Delta and Upper Egypt 
Figure 4 shows the competition on the limited farmland between green forages and other crops. The Egyptian agriculture, in particular, is totally set up on irrigation system. In winter, the buffalo farmers, of the two studied zones, gave the priority to produce clover for their animals. Besides, wheat is the main winter cereal grain crop. Some other crops and vegetables are cultivated in $18 \%$ of all the cultivated area of UEg while, this percentage did not exceed $1 \%$ in DEg in winter. Maize is the dominant crop, in the two studied zones, in summer season followed by Rice.

While, over one-fifth of cultivated area, in the two-studied zone, hada variety of crops and

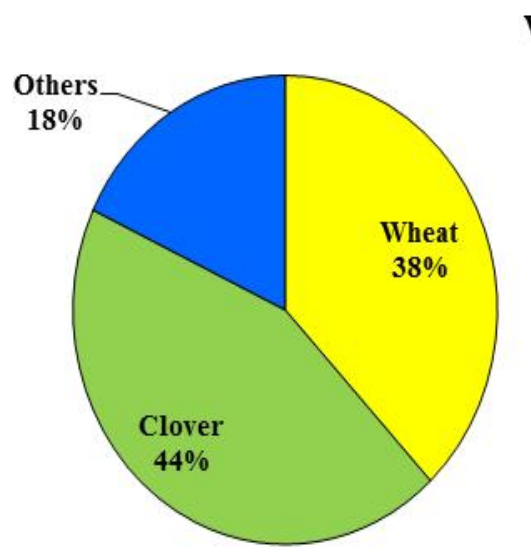

\section{Winter}

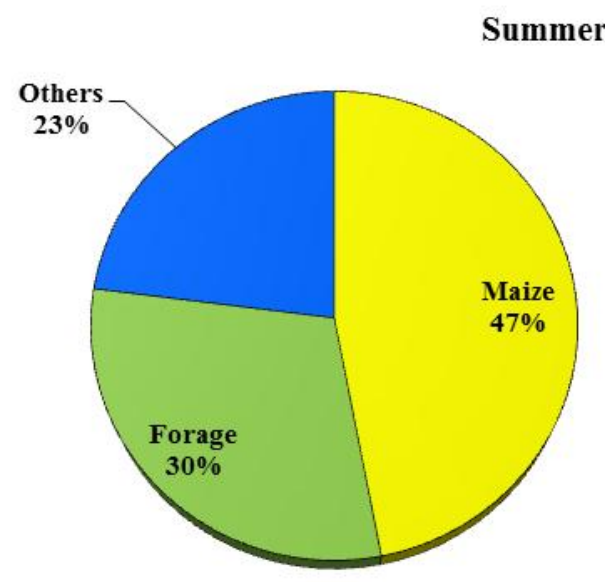

Upper Egypt vegetables. Furthermore, the green forage cultivated in summer represented about $30 \%$ and $10 \%$ of the cultivated land by buffalo farmers in UEg and DEg, respectively. There was imbalanced distribution of feedstuffs over the year; a surplus of green forages in winter and a sharp deficiency in summer. In winter, large areas of farmlands were cultivated with the Egyptian clover that is considered the most important green forage for livestock in Egypt. But in summer, a huge drop in these areas was noticed, particularly, in DEg. Farmlands devoted to cultivate forage decreased from $64 \%$ in winter to $10 \%$ in summer in $\mathrm{DEg}$, while a smaller decrease from $44 \%$ to $30 \%$ was found between winter and summer in UEg.
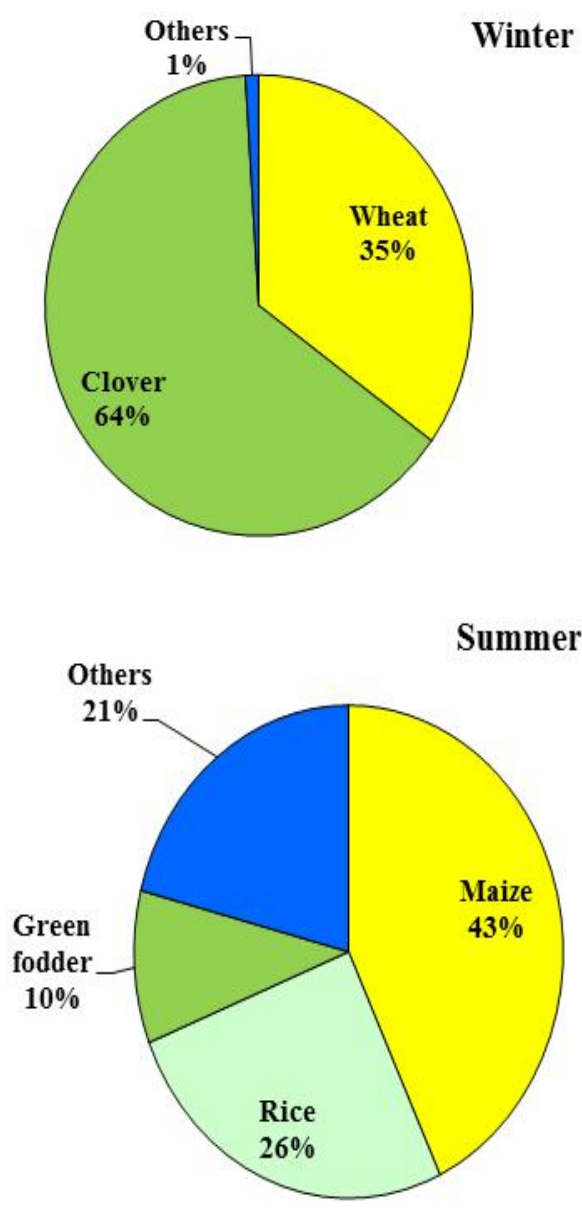

Delta Egypt

Figure 4. Cropping patterns of buffalo farmers land in Delta and Upper Egypt according to the season.

\section{Management practices:}

Results shown in Table (3) indicated that the majority of buffalo farmers regardless the zone, used natural mating. The majority of buffalo farmers did not possess bulls. Farmers of these herds, usually move the buffalo cow in heat to a neighboring farmer that owns a bull. Table (3) shows the basis used by buffalo farmers to choose the bulls to mate with buffalo cows. Age and displaying estrous signs were the two main methods used by buffalo farmers to determine the first time for breeding their buffalo heifers. 
Table 3. Breeding management in buffalo farms in Delta and Upper Egypt

\begin{tabular}{|c|c|c|c|c|}
\hline & \multicolumn{2}{|c|}{ Upper Egypt (UEg) } & \multicolumn{2}{|c|}{ Delta Egypt (DEg) } \\
\hline & Frequency & $\%$ & Frequency & $\%$ \\
\hline \multicolumn{5}{|l|}{ Type of breeding: } \\
\hline Natural service & 787 & $93^{\mathrm{a}}$ & 916 & $95^{\mathrm{a}}$ \\
\hline Artificial insemination & 15 & $2^{\mathrm{a}}$ & 11 & $1^{\mathrm{a}}$ \\
\hline Natural service $\&$ artificial insemination & 46 & $5^{\mathrm{a}}$ & 36 & $4^{\mathrm{a}}$ \\
\hline \multicolumn{5}{|l|}{ Case of the breeding bull: } \\
\hline Own bull & 17 & $2^{\mathrm{a}}$ & 48 & $5^{\mathrm{a}}$ \\
\hline neighbor bull & 831 & $98^{\mathrm{a}}$ & 915 & $95^{\mathrm{b}}$ \\
\hline \multicolumn{5}{|l|}{ Source of the breeding bull: } \\
\hline Single source & 758 & $89^{\mathrm{a}}$ & 762 & $79^{\mathrm{a}}$ \\
\hline Multiple sources & 90 & $11^{\mathrm{a}}$ & 201 & $21^{\mathrm{a}}$ \\
\hline \multicolumn{5}{|l|}{ Basis of choice a breeding bull: } \\
\hline Proximity & 668 & $79^{\mathrm{a}}$ & 627 & $65^{\mathrm{a}}$ \\
\hline Phenotype & 124 & $14^{\mathrm{a}}$ & 232 & $24^{\mathrm{a}}$ \\
\hline Reputation & 56 & $7^{\mathrm{a}}$ & 104 & $11^{\mathrm{a}}$ \\
\hline
\end{tabular}

${ }^{a, b}$ Different superscripts indicate significant differences between the zone categories $(P<0.05)$ for $\chi^{2}$ test.

\section{Buffaloes productive and reproductive performance:}

Results in Table 4 show the productive characteristics of the buffaloes maintained in both $\mathrm{DEg}$ and UEg. Significant difference $(\mathrm{P} \leq 0.0001)$ between the daily buffalo milk means was observed. On the other hand, buffalo of UEg significantly
$(\mathrm{P} \leq 0.002)$ produce milk for longer periods than those of DEg. Mean of total milk yield of buffaloes kept in DEg was significantly $(\mathrm{P} \leq 0.011)$ higher than that produced by buffaloes in UEg. Furthermore, means of parities which buffaloes give through their lifespan were significantly different $(\mathrm{P} \leq 0.0001)$.

Table 4. Productive performance of buffalo raised in Upper (UEg) and Delta (DEg) Egypt

\begin{tabular}{lllllll}
\hline Trait & Zone & Mean & SE & Min. & Max. & CV\% \\
\hline \multirow{2}{*}{ Daily milk yield/Kg } & UEg & $7.7^{\mathrm{a}}$ & 0.06 & 5 & 14 & 24 \\
& $\mathrm{Deg}$ & $8.2^{\mathrm{b}}$ & 0.06 & 5 & 14 & 25 \\
Total milk yield, kg & $\mathrm{UEg}$ & $1826^{\mathrm{a}}$ & 19 & 610 & 3843 & 30 \\
& $\mathrm{Deg}$ & $1899^{\mathrm{a}}$ & 21 & 610 & 5124 & 34 \\
Lactation period/day & $\mathrm{UEg}$ & $235^{\mathrm{a}}$ & 1.2 & 122 & 366 & 15 \\
& $\mathrm{Deg}$ & $232^{\mathrm{b}}$ & 1.4 & 122 & 366 & 19 \\
Lifespan * & $\mathrm{UEg}$ & $5.5^{\mathrm{a}}$ & 0.09 & 1 & 10 & 50 \\
& $\mathrm{DEg}$ & $4.7^{\mathrm{b}}$ & 0.07 & 1 & 10 & 48
\end{tabular}

$\overline{\mathrm{a}, \mathrm{b}}$ Different superscripts indicate significant differences between the zone categories $(P<0.05)$ for ANOVA test. Number of herds $=848$ for Upper Egypt and 963 for Lower Egypt. *=number of parities a female has accumulated before culling.

Information about reproductive performance of buffaloes kept in UEg and Deg are listed in Table 5. The average age at first calving for buffalo heifers raised in UEg was 31 months; it was significantly $(P \leq 0.0001)$ earlier than those raised in DEg (32 months). On the other hand, no significant difference $(P \geq 0.103)$ was found between sampled buffaloes kept under the two studied zones for days open. Its range was from 21 to 180 days with means of 67 and 70 days in UEg and DEg, respectively.

The variables used for PCA of UEg and DEg zones are reported in Tables (6 and 7), respectively. PCA for UEg, in total 15 variables were included in the PCA.Five principle components were with eigenvalues (The eigenvalue for a given factor measures the variance in all the variables which is accounted for by that factor) greater than 1 which explaining $67.9 \%$ of the total original variation in UEg. Ten PCs had eigenvalues greater than 0.5 in the UEg zone. The PCs eigenvalues ranged from 0.56 to 4.17 and on the whole, they explained $91.5 \%$ of the total original variation (Figure 5). PCA for DEg, in total 22 variables included in the PCA.Six principle components were with eigenvalues greater than one which explaining $82.1 \%$ of the total original variation in DEg. Seven PCs had eigenvalues greater than 0.5 in the DEg area. The PCs eigenvalues ranged from 0.96 to 6.92 and on the whole, they explained $86.5 \%$ of the total original variation (Figure 5). 
Table 5. Reproductive performance of buffalo raised in Upper (UEg) and Delta (DEg) Egypt

\begin{tabular}{llllllll}
\hline Trait & Zone & Farm no. & Mean & SE & Min. & Max. & CV\% \\
\hline \multirow{2}{*}{ Age at first calving (month) } & UEg & 622 & $31^{\mathrm{a}}$ & .18 & 24 & 38 & 14 \\
No. service per conception & DEg & 781 & $32^{\mathrm{b}}$ & .15 & 24 & 38 & 13 \\
(insemination) & $\mathrm{UEg}$ & 811 & $1.8^{\mathrm{a}}$ & .02 & 1 & 3 & 41 \\
\multirow{2}{*}{ Period from calving to first service (day) } & $\mathrm{DEg}$ & 895 & $1.6^{\mathrm{b}}$ & .02 & 1 & 3 & 41 \\
& $\mathrm{UEg}$ & 821 & $50^{\mathrm{a}}$ & .79 & 21 & 180 & 46 \\
Days open (day) & $\mathrm{UEg}$ & 820 & $53^{\mathrm{a}}$ & .88 & 21 & 150 & 49 \\
& $\mathrm{DEg}$ & 897 & $77^{\mathrm{a}}$ & 1.06 & 21 & 180 & 45 \\
Calving interval (day) & $\mathrm{UEg}$ & 815 & $385^{\mathrm{a}}$ & 1.13 & 21 & 180 & 49 \\
& $\mathrm{DEg}$ & 877 & $397^{\mathrm{b}}$ & 1.73 & 340 & 540 & 9 \\
a,b & & & 340 & 540 & 13 \\
\hline
\end{tabular}

${ }^{a, b}$ Different superscripts indicate significant differences between the zone categories $(P<0.05)$ for ANOVA test.
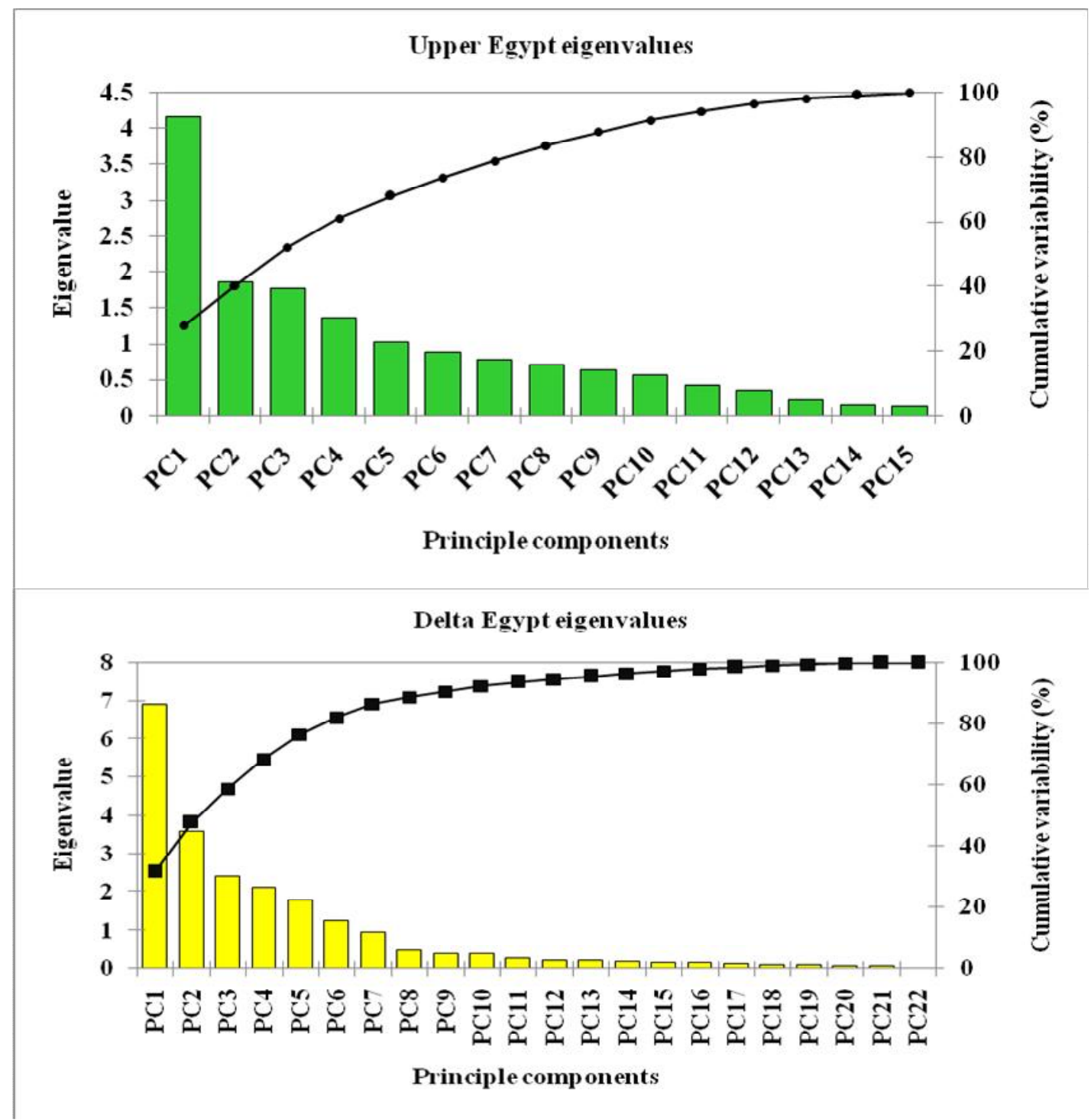

Figure 5. PC eigenvalues of Delta and Upper Egypt

Table 6 shows that the squared cosines of the UEg variables. The greater the squared cosine, the greater the link with corresponding variables axis. From the results of PCA, PC1, which explained $28.8 \%$ of variance, reflected the variables related with the possession of lands and farm animals. The PC2 explained $12.4 \%$ of variance. This component is mostly related to the farmer education. The PC3 explained $11.8 \%$ of the total variance. PC3 is positively correlated with the milk production traits. The PC4 and PC5 components explained 9.1\% and $6.9 \%$ of variance, respectively. These components are associated with reproductive management and land possession. 
Table 6. Squared cosines of the variables: Upper Egypt

\begin{tabular}{llllll}
\hline Variable & PC1 & PC2 & PC3 & PC4 & PC5 \\
\hline Educational level & 0.105 & 0.538 & 0.201 & 0.045 & 0.018 \\
Educational qualifications & 0.089 & 0.527 & 0.200 & 0.052 & 0.032 \\
Land possession System & 0.012 & 0.103 & 0.037 & 0.029 & 0.459 \\
Land possession, feddan & 0.788 & 0.003 & 0.039 & 0.000 & 0.004 \\
Buffalo number & 0.215 & 0.125 & 0.029 & 0.149 & 0.074 \\
Cattle number & 0.363 & 0.000 & 0.004 & 0.002 & 0.069 \\
Lactation period, day & 0.057 & 0.085 & 0.403 & 0.208 & 0.003 \\
Total milk yield, kg & 0.128 & 0.088 & 0.265 & 0.150 & 0.013 \\
Cultivated wheat, feddan & 0.666 & 0.009 & 0.023 & 0.006 & 0.018 \\
Cultivated maize, feddan & 0.558 & 0.018 & 0.051 & 0.050 & 0.017 \\
Cultivated clover, feddan & 0.696 & 0.019 & 0.073 & 0.013 & 0.006 \\
Cultivated forage, feddan & 0.328 & 0.063 & 0.026 & 0.128 & 0.018 \\
Period from calving to first service, day & 0.004 & 0.071 & 0.078 & 0.313 & 0.030 \\
Number of parities, parity & 0.135 & 0.000 & 0.000 & 0.175 & 0.257 \\
Basis of heifers are inseminated & 0.026 & 0.207 & 0.347 & 0.038 & 0.009 \\
\hline Valus in bold cortespond for
\end{tabular}

Values in bold correspond for each variable to the component for which the squared cosine is the largest

Table (7) shows the squared cosines of the DEg variables. The PC1 component explains $31.4 \%$ of variance, the PC2 explains $16.4 \%$, the $\mathrm{PC} 3$ is $10.9 \%$, the PC4 is $9.6 \%$ and the PC5 is $8.1 \%$ of total variance. From the results of $\mathrm{PC}$ analysis, the $\mathrm{PC} 1$ component reflected the variables related to the possession of buffalo and buffaloes herd structure. The PC2 component included the variables associated with possession of land and other farm animals. The PC3 considered the variables related to the milk production and reproduction traits. While, the PC4 comprises of forge cultivated areas. The PC5 reflected the variables related with the farmer education.

Table 7. Squared cosines of the variables: Delta Egypt

\begin{tabular}{llllll}
\hline Variable & PC1 & PC2 & PC3 & PC4 & PC5 \\
\hline Buffalo number & 0.888 & 0.078 & 0.001 & 0.021 & 0.001 \\
Number of heifers $<1$ year & 0.741 & 0.009 & 0.002 & 0.119 & 0.006 \\
Number male calves $<1$ year & 0.738 & 0.045 & 0.006 & 0.041 & 0.000 \\
Number of heifers 1-2 year & 0.688 & 0.072 & 0.004 & 0.006 & 0.011 \\
Number of first lactation Buffalo & 0.682 & 0.052 & 0.000 & 0.044 & 0.013 \\
Number of 2-3 lactation Buffalo & 0.566 & 0.080 & 0.012 & 0.079 & 0.000 \\
Number of total Employee & 0.457 & 0.058 & 0.004 & 0.108 & 0.016 \\
Number of fattening male calves $>1$ & 0.446 & 0.038 & 0.013 & 0.038 & 0.032 \\
Number of 6 th or more lactation Buffalo & 0.439 & 0.071 & 0.017 & 0.063 & 0.000 \\
Number of 4-5 lactation Buffalo & 0.386 & 0.031 & 0.016 & 0.067 & 0.006 \\
Size of cultivated clover, feddan & 0.206 & 0.180 & 0.004 & 0.470 & 0.064 \\
Size of cultivated forage, feddan & 0.184 & 0.023 & 0.007 & 0.593 & 0.072 \\
Land possession, feddan & 0.175 & 0.669 & 0.002 & 0.008 & 0.002 \\
Cattle possession, no. & 0.144 & 0.660 & 0.006 & 0.090 & 0.001 \\
Size of cultivated maize, feddan & 0.089 & 0.750 & 0.005 & 0.078 & 0.001 \\
Sheep \& goats possession, no. & 0.062 & 0.746 & 0.003 & 0.078 & 0.002 \\
Total milk yield, kg & 0.013 & 0.000 & 0.065 & 0.000 & 0.005 \\
Educational level & 0.005 & 0.015 & 0.036 & 0.073 & 0.765 \\
Calving interval, day & 0.002 & 0.007 & 0.608 & 0.022 & 0.013 \\
Period from calving to first service, day & 0.002 & 0.000 & 0.741 & 0.013 & 0.011 \\
Educational qualifications & 0.002 & 0.015 & 0.035 & 0.078 & 0.747 \\
Days open, day & 0.001 & 0.001 & 0.815 & 0.022 & 0.020 \\
\hline Valus in bold
\end{tabular}

Values in bold correspond for each variable to the component for which the squared cosine is the largest

\section{DISCUSSION}

The large illiteracy percentage within rural areas of UEg in the current study is in agreement with Hopkins and Saad (2004). They attributed this high percentage to the poverty. The highest rate of poverty in Egypt was recorded in UEg (UN, 2013).
Inadequate facilities such as insufficient numbers of schools or long distances between schools and households may also increase illiteracy rate. Illiteracy negatively affects the development of livestock systems as persuading illiterates to stop old practices or adopt new technology is difficult. 
Besides, the averages landholding per household (1.1 ha in UEga nd 1.5 hain DEg) match with those reported by the World Bank (2006). Similar result was obtained by CAPMAS (2008), reporting that about $81 \%$ of the average landholders in $\mathrm{DEg}$ cultivate 1.6 ha or less. On the other hand, about 84 $\%$ of the landholders of UEg cultivate less than one ha. The World Bank (2009) estimated an average of 0.07 ha and 0.13 ha per capita in UEg and DEg, respectively. This would indicate that one farm may be operated by more than one household. Hopkins and Saad (2004) indicated that higher values in Deg were due to more reclaimed lands.

Moreover, the gap in the summer season between production and demand of green forages is a result of the competition of strategic crops on limited farm land. Farmers face this gap by depending on the available limited green summer forages, crop leaves, concentrates, crop residues, silage, straw and hay.

The reported small herd sizes in both studied zones are attributed to the limited availability of feed resources. Moreover, farmers usually tend to keep various species and produce a variety of products trying to use the available limited resources efficiently.

The great variation in milk quantities produced by buffalo members involved in the current study refers to the existence of a genetic variability. Thus, selection programs may effectively improve the buffalo's productivity (Malhado et al., 2013). Some individuals within the current study could produce 14 $\mathrm{kg}$ as daily milk for a long lactation period (12 months).

Means of total milk yield, in the current study, were higher than $1270 \mathrm{~kg}, 1256 \mathrm{~kg}, 1591 \mathrm{~kg}$ and $1536 \mathrm{~kg}$ reported by El-Arian et al. (2001), Khalil and El-Ashmawy (2008), Khattab et al. (2010) and Ibrahim et al. (2012), respectively. On the other hand, they were lower than $2256 \mathrm{~kg}, 1970 \mathrm{~kg}$ and $2262 \mathrm{~kg}$ stated by Badran et al. (2002), Ahmed et al. (2006) and El-Awady et al. (2016), respectively. Different estimates of milk production confirm the potential productivity in the Egyptian buffaloes that has not yet been exploited.

About two-thirds of the farmers did not use AI because of its unavailability. This high percentage indicated that the observed high use of natural mating over AI may not reveal the true farmers' choice, but it is the only available option. Similar results were reported by Baltenweck et al. (2004) in Kenya and by Mugisha et al. (2014) in Uganda. Absence or lacks of AI centers are not the only reasons that make AI unavailable. Large distances between a buffalo herd location and the AI centers may cause unavailability. On the other hand, the high proportion of farmers who did not trust AI refers to the information gap among farmers about the importance of AI technique. It is attributed to the weakness of the extension services. Where, over than $77 \%$ of farmers, in the two studied zones, complained of the weak role of agricultural extension. High percentages of illiteracy, among buffalo farmers, namely in UEg add extra obstacles to accept new technologies.

Furthermore, different estimates of Age at first calving could be due to differences in management practices and differences in weather conditions (Gupta et al., 2012). The values of the present study are located between $25.1 \pm 0.7$ and $39 \pm 3$ months that were reported by (Marai et al., 2009) and Khattab and Kawthar (2007), respectively. Raising buffalo heifers under proper management conditions lead to early onset of puberty and so an early age at first calving (Marai et al., 2009).

The long calving intervals for DEg buffaloes than those of UEg confirms the negative association between milk yield and fertility (Andersen-Ranberg et al., 2005; Ramos et al., 2006; Malhado et al., 2009; Toghiani, 2012 and Bicalho et al., 2014). A negative energy balance during early lactation, in high producing dairy animals, could affect the onset of estrus leading to longer calving intervals (Ojango and Pollott, 2001 and Hussein et al., 2013). Therefore, selection for high milk yield, in dairy animals, is usually accompanied by a decrease in fertility that leads to low reproductive performance (Oltenacu and Broom, 2010). The obtained results were close to the ideal period of calving interval that permits nearly a calf every year. Besides, the current study estimates were close to the 395 days reported by Fooda et al. (2011). But they were shorter than the 555, 496 and 402 days reported by Badran et al. (2005), Hassan et al. (2005) and Marai et al. (2009), respectively.

The high number of services/conception for buffalo raised in UEg than those raised in DEg may be attributed to the differences in the climate conditions within the two studied zones. High temperatures and humidity in UEg may negatively affect the rate of conception resulting in increasing number of services per conception. This result is in agreement with Zoheir et al. (2007) and Ali et al. (2011).

From the principal component result, the first PC was a measure of the land and animal possession and to some extent land size of different cultivated crops in UE. Buffalo number increases with increasing size of farm possession. When farm size increases, it guarantees a greater feed being available. The amount of animal feed availability determines the herd size that farmer can keep (Debele and Verschuur, 2014). While, in DE, was a measure of buffalo possession, buffalo herd structure and to some extent number of total employees in the buffalo holder farms. Number of employees increases with increasing buffalo herd size. In UE, the second principal component was a measure of the educational level and qualifications. But in DE, was a measure of the land possession, size of cultivated maize and other farm animal possession. The size of cultivated maize increases with increasing land possession and that reflect the increasing of the possession of other farm animals through providing the roughage feed during the summer season. The 
third principal component was a measure of the length of lactation period, the quantity of the total milk yield, and the method of heifers are inseminated in UE. The amount of total milk yield increases with increasing length of the lactation period (Mellado et al., 2016). However, in DE was a measure of the reproductive measurements. The calving interval decreases with decreasing the period from calving to first service and days open (Haile-Mariam et al., 2003). In DE, the fourth principal component was a measure of the length of the period from calving to first service. It measures the quality of reproductive management (Ramos et al., 2016). So, in DE was a measure of the size of cultivated clover and the size of cultivated forage. The size of cultivated forge in the summer increases by increasing the size of cultivated clover in the winter. The fifth principal component was a measure of the size of land possession and the time of farm saving animal in production in UE. Number of parities increase with increasing size of land possession. Moreover, that reflects the ability of buffalo holders to provide their milking buffalo by feedstuff. In DE, The fifth principal component was a measure of the educational level and qualifications. The PC analysis showed different results between the Delta and Upper Egypt buffalo farming. Where, these results reflect the difference between the components that cause the variable between UEg and DEg.

\section{CONCLUSION}

It is concluded that buffalo herd sizes and landholding were higher in DEg than in UEg. Productivity of buffaloes is better in DEg, but their reproduction performance was a slightly better in UEg. Medium and low estimates of coefficients of variation of productive and reproductive traits indicated the high variability between individuals and the influence of management practices. The variables affected in the production system were different in Delta and Upper Egypt. Development of the Egyptian buffaloes needs suitable breeding programs, using untraditional feed resources, good veterinary and extension services, development village markets and introduction of storage and grading products facilities. They buffalo farming systems in Egypt needs more studies to recognize the opportunities of improvement and to maximize the productivity and profitability of the system.

\section{ACKNOWLEDGMENTS}

This research was conducted within the framework of the project no. 1010 titled "Sustainable Breeding Program of Egyptian Buffalo" funded by Science and Technology Development Foundation (STDF).

\section{REFERENCES}

Ahmed, A. M., A.M. Hashim, R.R. Sadek, and A.S. Abdel-Aziz, 2006. Salient features of mixed farming system in newly reclaimed land in
Egypt. Proceedings of the 13th Conference of the Egyptian Society of Animal Production. Cairo, Egypt, 10-11 Dec., 43, 159-169.

Ali, A., Javed, K., Ahmad, N., and Rehman, S. U. 2011. Environmental factors affecting some reproductive traits in Nili Ravi buffaloes. J. Anim. Plant Sci., 21(4), 868-871.

Andersen-Ranberg, I. M., Klemetsdal, G., Heringstad, B., and Steine, T. 2005. Heritabilities, genetic correlations and genetic change for female fertility and protein yield in Norwegian dairy cattle. J. Dairy Sci., 88, 348355.

Badran, A. E., El-Barbary, A., Bedeir, L., and Shafie, O. M. 2005.Inbreeding and reproductive performance in Egyptian buffaloes. Buffalo J., 2, 183-188.

Badran, A. E., El-Barbary, A., Mahdy, A. E., andAssar, G. M. 2002. Genetic and non-genetic factors affecting the lifetime production traits in Egyptian buffaloes. Buffalo J., 18, 235-241.

Baltenweck, I., Ouma, R., Anunda, F., Mwai, O., and Romney, D. 2004. Artificialor natural insemination: the demand for breeding services by smallholders. Paper presented at the ninth KARI (Kenya Agricultural Research Institute) annual scientific conference and agricultural research forum, Nairobi, Kenya, 12 Nov. Nairobi: ILRI.

Bicalho, R.C., Foditsch, C., Gilbert, R., and Oikonomou, G. 2014. The effect of sire predicted transmitting ability for production traits on fertility, survivability, and health of Holstein dairy cows. Theriogenology, 81(2), 257-265.

CAPMAS. 2008. The Statistical Year Book 2007, Central Agency for Public Mobilization and Statistics, Cairo, Egypt.

Das, G.C., Das, P.K., Deori, S., Mazumdar, H., Bhattacharyya, B. N., and Phookan, A. 2017. Seasonal Variation in the Characteristics of the Swamp Buffalo Semen of Northeast India. Buffalo Bulletin, 36(1), 215-219.

Debele, G., and Verschuur, M. 2014. Assessment of factors and factors affecting milk value chain in smallholder dairy farmers: A case study of Ada'a District, East Shawa Zone of Oromia regional State, Ethiopia. Afr. J. Agric. Res., 9(3), 345352.

El Nahas, S. M., Vibras, M. A., and Taha, D. A. 2013.Genetic characterization of Egyptian buffalo CSN3 gene. J. Gene. Eng. and Bio., 11(2), 123-127.

El-Arian, M. N., Mourad, K. A., and Khattab, A. S. 2001.A comparison of different selection indices for genetic improvement of some milk traits in a herd of Egyptian buffaloes. J. Agric. Sci., 26, 2687-2695.

El-Awady, H.G., Ashour, A.F., and Shamia, S. M. 2016.Genetic and Economic Evaluation for the Relationship between Somatic Cell Counts, Milk 
Yield and Milk Constituents in Egyptian Buffaloes. Buffalo Bulletin, 35 (4), 607-618.

FAOSTAT. 2014. Statistical database. Food and Agriculture Organization. http://faostat.fao.org (Accessed 10.02.17).

Fooda, T. A., Elbeltagy, A. R., Laila, R. H., and Set El-habaeib, S. A. 2011. Evaluation of Egyptian buffaloes crossing with Italian buffaloes for reproductive traits. J. Am. Sci., 7(7), 209-213.

Galal, S., and Elbeltagy, A. 2006.Achievement of research in the field of buffalo production in Egypt. WAAP Book of the year 2006, pp 177188.

Gupta, J. P, Sachdeva, G. K, Gandhi, R. S., and Cahkaravarty, A. K. 2012.Non-genetic factors influencing growth and production performance in Murrah Buffaloes. Indian J. Dairy Sci., 65(3), 239-241.

Haile-Mariam, M., Morton, J.M., and Goddard M.E. 2003. Estimates of genetic parameters for fertility traits of Australian Holstein-Friesian cattle. Anim. Sci., 76, 35-42.

Hassan, H. Z., Mourad, K. A., Ashraf, M. F., and Kotby, E. A. 2005.Focusing over some physiological and productive aspects in Egyptian buffaloes herd. Egypt. J. Agric. Res., 83(2), 907915.

Hopkins, N., and Saad, R. 2004. The region of Upper Egypt: Identity and change. (Eds.). The American University of Cairo press. Egypt. pp 124.

Hussein, H. A., Senosy, W., and Abdellah, M. R. 2013.Relationship among uterine involution, ovarian activity, blood metabolites and subsequent reproductive performance in Egyptian buffaloes. J. Anim. Sci. 3(1), 59-69.

IBM Corp. Released. 2012. IBM SPSS Statistics for Windows, Version 21.0. Armonk, NY: IBM Corp.

Ibrahim, M. A., Khattab, A. S., Set El- Habaeib, S. A., and Tozser, J. 2012. Genetic 485 parameters for buffalo milk yield and milk quality traits using animal model. AWETH, 8(2), 175-182.

Ibrahim, M.A., and Abdelrazek, I. M. 2012. Water buffalo for our next generation in Egypt and in the world. Anim. Sci. Series D., Vol. LV, 183192.

Khalil, M. A., and El-Ashmawy, M. M. I. 2008. Characterization of dairy farming systems in Upper Egypt. Proceedings of the $14^{\text {th }}$ Conference of the Egyptian Society of Animal Production. Cairo, Egypt, 17-18 Dec., 45: 43-55.

Khalil, M. A., and Sammour, H. B. 2006. Economics of some feeding packages application under mixed production system at El-Beheira governorate. Proceedings of the 13th Conference of the Egyptian Society of Animal Production. Cairo, Egypt, 10-11 Dec., 43: 325-339.

Khattab, A. S., and Kawther, A. M. 2007.Inbreeding and its effects on some productive and reproductive traits in a herd of Egyptian buffaloes. Ital. J. Anim. Sci., 6 (2), 275-278.
Khattab, A. S., Mourad, A., and Awad, S. 2010. Estimation of genetic parameters and breeding values for some productive traits on Egyptian buffaloes. Revista Veterinaria, 21(1), 1046-1048.

Malhado, C. H. M., Ramos, A. A., and Carneiro, P. L. S. 2009. Genetic parameters of reproductive and productive traits in cross-breed water buffaloes in Brazil. Revista Brasileira de Saude Producao Animal, 10, 830-839.

Malhado, C. H. M., Ramos, A. A., Carneiro, P. L. S., Souza, J. C., andCarrillo, J. A. 2013. Genetic parameters for milk yield and lactation length of crossbred buffaloes from Brazil by Bayesian interference. Buffalo Bulletin, 32(2), 646-649.

MALR. 2011. Statistics of livestock. The Ministry of Agriculture and Land Reclamation/Egypt.

Marai, I. F. M., Daader, A. H., Soliman, A. M., and El-Menshawy, S. M. S. 2009. Non-genetic factors affecting growth and reproduction traits of buffaloes under dry management housing (in sub-tropical environment) in Egypt. Livest. Res. for Rural Devel, 21, 3.

Mellado, M., Flores, J.M., de Santiago, A., Veliz, F.G., Macías-Cruz, U., Avendaño-Reyes, L., and García, J.E. 2016. Extended lactation in highyielding Holstein cows: Characterization of milk yield and risk factors for lactations $>450$ days. Livest. $\quad$ Sci., $189, \quad 50$ 55.https://doi.org/10.1016/j.livsci.2016.05.004

Moioli, B., and Borghese, A. 2005.Buffalo Production and Research. Chap.3buffalo breeds and management systems. Food and Agriculture Organization, Rome, Italy, pp 51-76.

Mugisha, A., Kayiizi, V., Owiny, D., and Mburu, J. 2014. Breeding services and the factors influencing their use on smallholder dairy farms in central Uganda. Veterinary Medicine International. Article ID 169380, 6 pages.

Nilforooshan, M. A.,andEdriss, M. A. 2004.Effect of age at first calving on some productive and longevity traits in Iranian Holsteins of the Isfahan Province. J. Dairy Sci., 87(7), 21302135.https://doi.org/10.3168/jds.s00220302(04)70032-6

Ojango, J. M. K., and Pollott, G. E. 2001.Genetics of milk yield and fertility traits in Holstein-Friesian cattle on large-scale Kenyan farms. J. Anim. Sci., 79, 1742-1750.

Oltenacu, P. A., and Broom, D. M. 2010. The impact of genetic selection for increased milk yield on the welfare of dairy cows. Anim. Welfare, 19, $39-49$.

Pundir, R.K., Singh, P. K., Singh1, K. P. and Dangi, P. S. 2011. Factor analysis of biometric traits of kankrej cows to explain body conformation. Asian-Aust. J. Anim. Sci., 24(4), 449-456.

Ramos, A. A., Malhado, C. H. M., and Carneiro, P. L. S. 2006.Phenotypic and genetic characterization of the milk yield and calving interval in buffalo of the Murrah breed. Pesquisa Agropecuaria Brasileira, 41, 1261-1267. 
Ramos, R. S., Bryan,K. Velez,J. Binelli,M.,and Pinedo, P. 2016. Reproductive performance in a large organic dairy farm in the southern united states. Proceedings of the $30^{\text {th }}$ Annual Meeting of the Brazilian Embryo Technology Society (SBTE); Foz do Iguaçu, PR, Brazil, 25-27 Aug. Abst.

Sadek, M. H., Al-Aboud, A. Z., and Ashmawy, A. A. 2006.Factor analysis of body measurements in Arabian horses. J. Anim. Breed Genet, 123, 369377.

Toghiani, S. 2012.Genetic relationships between production traits and reproductive performance in Holstein dairy cows. Archiv Tierzucht, 55(5), 458-468.

UN. 2013. The status of poverty and food security in Egypt. Newsletter from the United Nations in Egypt. May. Issue 35.
Wanapat, M., and Chanthakhoun, V. 2015. Buffalo Production for Emerging Market as a Potential Animal Protein Source for Global Population. Buffalo Bulletin, 34(2), 169-180.

World Bank. 2006. Arab Republic of Egypt: Upper Egypt-challenges and priorities for rural development. Report No. 36432-EG.

World Bank. 2009. Arab Republic of Egypt Upper Egypt: pathways to shared growth. Report No. 49086-EG.

XLSTAT. 2016. Data analysis and statistical solution for MS Excel. Addinsoft.

Zoheir, K. M. A., Abdoon, A. S., Mahrous, K. F., Amer, M. A., Zaher, M. M., Li-Guo, Y., and ElNahass, E. M. 2007. Effects of season on the quality and in vitro maturation rate of Egyptian buffalo (Bubalus bubalis) Oocytes. J. Cell and Anim. Bio., 1(2), 29-33.

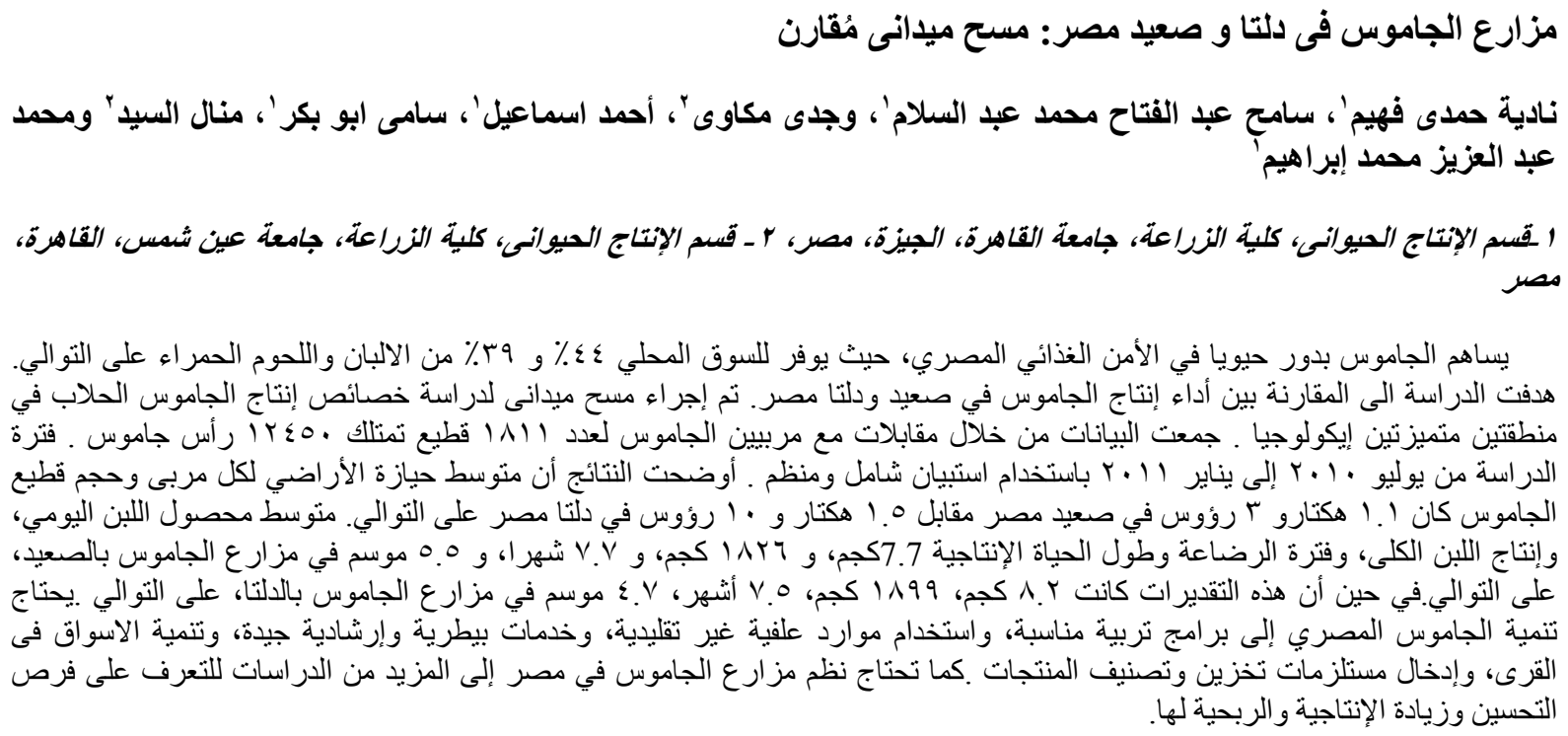

